\title{
Synthesis, structure and electrical conductivity of fulvalenium salts of cobalt bis(dicarbollide) anion and its derivatives
}

\author{
VLADIMIR BREGADZE ${ }^{\mathrm{a},}$, IGOR SIVAEV ${ }^{\mathrm{a}}$, IRINA LOBANOVA ${ }^{\mathrm{a}}$, OLGA KAZHEVA $^{\mathrm{b}}$, \\ GRIGORII ALEXANDROV $^{\mathrm{c}}$, ANDREY KRAVCHENKO ${ }^{\mathrm{d}}$, VLADIMIR STARODUB $^{\mathrm{d}, \mathrm{e}}$, \\ LEV BURAVOV $^{\mathrm{b}}$, LEV TITOV $^{\mathrm{b}}$ and OLEG DYACHENKO ${ }^{\mathrm{b}}$ \\ ${ }^{a} A . N$. Nesmeyanov Institute of Organoelement Compounds, Russian Academy of Sciences, \\ Vavilov Str. 28, 119991, Moscow, Russia \\ ${ }^{\mathrm{b}}$ Institute of Problems of Chemical Physics, Russian Academy of Sciences, Semenov Av. 1, 142432, \\ Chernogolovka, Moscow Region, Russia \\ ${ }^{c}$ N.S. Kurnakov Institute of General and Inorganic Chemistry, Russian Academy of Sciences, \\ Leninskii Prosp. 31, 119991, Moscow, Russia \\ ${ }^{\mathrm{d}}$ V.N. Karazin Kharkiv National University, Svoboda Sq. 4, 61077, Kharkiv, Ukraine \\ ${ }^{\mathrm{e}}$ Institute of Chemistry, Jan Kochanowski University, 5 Chęcińska Str. 5, 25020, Kielce, Poland \\ e-mail: bre@ineos.ac.ru
}

\begin{abstract}
TTF, TTF-BMDT, TTF-BEDT and TMTSF cation radical salts of cobalt bis(dicarbollide) anion $\left[3,3^{\prime}-\mathrm{Co}\left(1,2-\mathrm{C}_{2} \mathrm{~B}_{9} \mathrm{H}_{11}\right)_{2}\right]^{-}$and its derivatives are prepared and their crystal structures and electrical conductivities are determined. Some regularities in the crystal structures of the TTF-based radical cation salts prepared are also discussed.
\end{abstract}

Keywords. Cobalt bis(dicarbollide); tetrathiafulvalenium; bis(methylenedithio)tetrathia-fulvalenium; bis(ethylenedithio)tetrathiafulvalenium; tetramethyltetraselenafulvalenium; crystal structure.

\section{Introduction}

Radical cation salts and charge transfer complexes based on tetrathiafulvalene (TTF) and their derivatives constitute a wide class of organic materials with transport properties ranging from insulating to superconducting. ${ }^{1,2}$ Conductivity in these materials occur via the $\pi$-electron donor network made up of stacks or sheets of closely packed radical cations. The packing of radical cations in the solid state was found to be a crucial parameter determining conductivity of the target compound and depends strongly on the nature of counter ions. Until recently the most typical counter-ions used for design of molecular materials were simple inorganic monoanions of the type $\mathrm{Cl}^{-}, \mathrm{Br}^{-}, \mathrm{I}_{3}^{-}, \mathrm{PF}_{6}^{-}, \mathrm{AsF}_{6}^{-}, \mathrm{BF}_{4}^{-}, \mathrm{ClO}_{4}^{-}$, etc. Organometallic chemistry provides a wide choice of metal complexes of various sizes and charges that can be used as charge-compensating counter-ions of the conducting radical cation salts. The bis(1,2dicarbollide) complexes of the iron group metals $\left[3,3^{\prime}-\mathrm{M}\left(1,2-\mathrm{C}_{2} \mathrm{~B}_{9} \mathrm{H}_{10}\right)_{2}\right]^{-} \quad(\mathrm{M}=\mathrm{Fe}, \mathrm{Co}, \quad \mathrm{Ni})^{3,4}$ are

*For correspondence known to demonstrate extraordinary stability due to the delocalized cluster bonding the transition metal with ligand orbitals and can be considered as charge-compensating counter-ions for synthesis of new radical cation-based molecular materials. ${ }^{5}$ These complexes could be easily modified by substitution of hydrogen atoms at carbon and boron atoms of the dicarbollide ligands for various non-hydrogen atoms and functional groups. That opens practically unlimited perspectives of their modification and counter-ions of increasing complexity, with a variety of volumes, connectivity, shapes and charges can be prepared in this way. ${ }^{3,4,6}$ It was demonstrated that an introduction of substituents which are capable of hydrogen bond formation provides important strategy for molecular design to control molecular arrangement in charge-transfer complexes and salts. ${ }^{7}$

Recently we started systematic study of effect of various substituents in cobalt bis(dicarbollide) anion $\left[3,3^{\prime}-\mathrm{Co}\left(1,2-\mathrm{C}_{2} \mathrm{~B}_{9} \mathrm{H}_{10}\right)_{2}\right]^{-}$(figure 1) on crystal packing and physical properties of its salts with TTFbased radical cations. ${ }^{8-11}$ In this study we describe some regularities in the crystal structures of the TTF-based radical cation salts prepared. 


\section{Synthesis}

Crystals of radical cation salts (TTF) [3,3'-Co(1,2$\left.\left.\mathrm{C}_{2} \mathrm{~B}_{9} \mathrm{C}_{2} \mathrm{H}_{11}\right)_{2}\right]{ }^{8} \quad$ (BMDT-TTF) [3,3'-Co(1,2$\left.\left.\mathrm{C}_{2} \mathrm{~B}_{9} \mathrm{H}_{11}\right)_{2}\right],{ }^{9}$ (BEDT-TTF) $\left[3,3^{\prime}-\mathrm{Co}\left(1,2-\mathrm{C}_{2} \mathrm{~B}_{9} \mathrm{H}_{11}\right)_{2}\right]{ }^{8}$ $(\mathrm{BEDT}-\mathrm{TTF})_{2} \quad\left[3,3^{\prime}-\mathrm{Co}\left(1,2-\mathrm{C}_{2} \mathrm{~B}_{9} \mathrm{H}_{11}\right)_{2}\right],{ }^{9} \quad(\mathrm{TMTSF})_{2}$ $\left[3,3^{\prime}-\mathrm{Co}\left(1,2-\mathrm{C}_{2} \mathrm{~B}_{9} \mathrm{H}_{11}\right)_{2}\right],{ }^{8} \quad$ (BMDT-TTF $)_{4} \quad\left[8,8^{\prime}-\mathrm{Br}_{2}-\right.$ $\left.3,3^{\prime}-\mathrm{Co}\left(1,2-\mathrm{C}_{2} \mathrm{~B}_{9} \mathrm{H}_{10}\right)_{2}\right],{ }^{10}$ (BEDT-TTF) $\quad\left[8,8^{\prime}-\mathrm{Br}_{2}-\right.$ $\left.3,3^{\prime}-\mathrm{Co}\left(1,2-\mathrm{C}_{2} \mathrm{~B}_{9} \mathrm{H}_{10}\right)_{2}\right],{ }^{10} \quad$ (BEDT-TTF $)_{2} \quad\left[8,8^{\prime}-\mathrm{Br}_{2}-\right.$ $\left.3,3^{\prime}-\mathrm{Co}\left(1,2-\mathrm{C}_{2} \mathrm{~B}_{9} \mathrm{H}_{10}\right)_{2}\right],{ }^{10} \quad$ (BEDT-TTF $)_{2} \quad\left[8-\mathrm{I}-3,3^{\prime}-\right.$ $\left.\mathrm{Co}\left(1,2-\mathrm{C}_{2} \mathrm{~B}_{9} \mathrm{H}_{10}\right) \quad\left(1^{\prime}, 2^{\prime}-\mathrm{C}_{2} \mathrm{~B}_{9} \mathrm{H}_{11}\right)\right],{ }^{9} \quad$ (TTF) $\left[8,8^{\prime}-\mathrm{I}_{2}-\right.$ $\left.3,3^{\prime}-\mathrm{Co}\left(1,2-\mathrm{C}_{2} \mathrm{~B}_{9} \mathrm{H}_{10}\right)_{2}\right],{ }^{11} \quad$ (BMDT-TTF) ${ }_{4} \quad\left[8,8^{\prime}-\mathrm{I}_{2}-\right.$ $\left.3,3^{\prime}-\mathrm{Co}\left(1,2-\mathrm{C}_{2} \mathrm{~B}_{9} \mathrm{H}_{10}\right)_{2}\right]^{11}$ and (BEDT-TTF $)_{2}\left[8,8^{\prime}-\mathrm{I}_{2}-\right.$ $\left.3,3^{\prime}-\mathrm{Co}\left(1,2-\mathrm{C}_{2} \mathrm{~B}_{9} \mathrm{H}_{10}\right)_{2}\right]^{11}$ were grown by electrochemical oxidation of $\pi$-donors (tetrathiafulvalene [TTF], bis(methylenedithio)tetrathiafulvalene [BMDTTTF], bis (ethylenedithio)-tetrathiafulvalene [BEDTTTF] and tetramethyltetraselenafulvalene [TMTSF]) in the presence of the corresponding cobalt bis (dicarbollides) in a two-electrode H-cell under galvanostatic conditions during 3-5 weeks. Some radical cation salts were prepared in the presence of 18-crown-6. All crystals were obtained using 1,1,2trichloroethane or 1,1,2-trichloroethane-acetonitrile $(20: 1)$ as solvents.

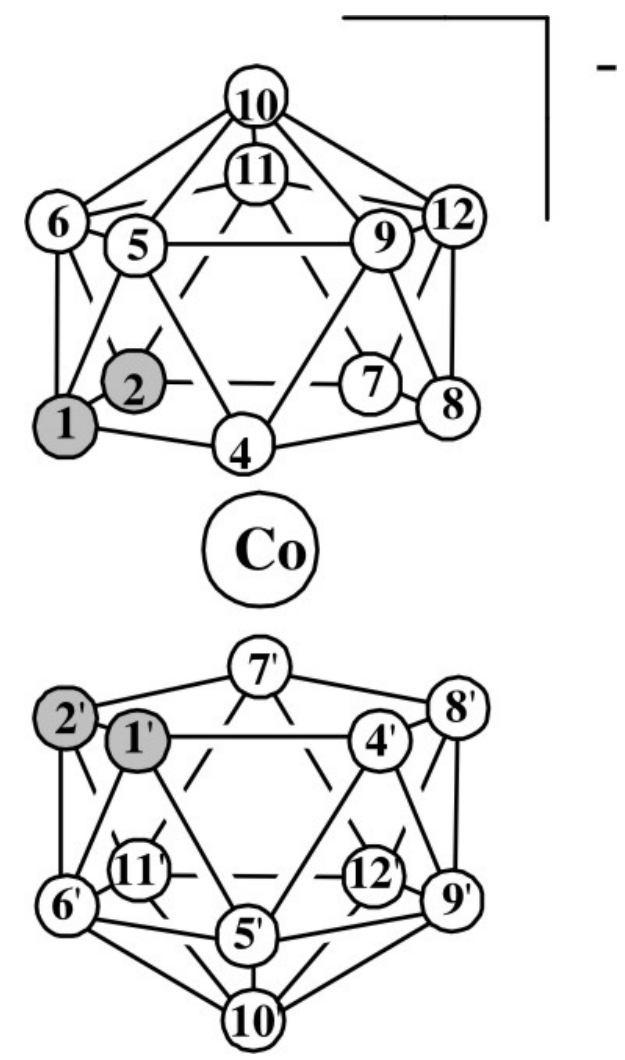

Figure 1. Structure and numbering of atoms in the $\left[3,3^{\prime}-\mathrm{Co}\left(1,2-\mathrm{C}_{2} \mathrm{~B}_{9} \mathrm{H}_{11}\right)_{2}\right]^{-}$anion.

\section{Results and discussion}

A hot focus of research in contemporary material science is building multifunctionality of materials and current synthetic efforts are aimed towards to design novel materials that combine in the same crystal lattice two or more physical properties which are difficult or impossible to achieve in continuous lattice solids. Since the majority of the TTF-based salts consist of discrete layers of cationic and anionic components, it should be possible to prepare new molecular materials with coexistence of properties, or materials exhibiting novel properties due to the mutual interaction between the different layers or individual networks. As a result, increasing attention is now being focused on synthesis of magnetic molecular conductors, where components with magnetic properties can be introduced by anionic complexes with paramagnetic centers. ${ }^{12}$ The bis $(1,2-$ dicarbollide) complexes of the iron group metals $\left[3,3^{\prime}-\mathrm{M}\left(1,2-\mathrm{C}_{2} \mathrm{~B}_{9} \mathrm{H}_{10}\right)_{2}\right]^{-}(\mathrm{M}=\mathrm{Fe}, \mathrm{Co}, \mathrm{Ni})$ have very close dimensions and demonstrate rather similar chemical properties, whereas their magnetic characteristics are different. It should be noted that diamagnetic cobalt bis(dicarbollide) and their derivatives at present are much more studied than their paramagnetic iron and nickel analogues. The main reason here is simple and reliable characterization of diamagnetic compounds by NMR spectroscopy, whereas characterization of substituted paramagnetic derivatives of metallacarboranes are rather difficult and tedious. However, very close shape and size of the bis(dicarbollide) complexes give possibility to use diamagnetic cobalt bis(dicarbollide)s as model compounds for crystal structure design of molecular materials containing related paramagnetic counterions.

The most part of the parent bis(1,2-dicarbollide) complexes with the same radical cations ((TTF) $\left[3,3^{\prime}-\mathrm{M}\left(1,2-\mathrm{C}_{2} \mathrm{~B}_{9} \mathrm{H}_{11}\right)_{2}\right], \mathrm{M}=\mathrm{Co},{ }^{8} \mathrm{Fe},{ }^{13} \mathrm{Ni}^{13}$ (figure 2a); (BEDT-TTF $)_{2}\left[3,3^{\prime}-\mathrm{M}\left(1,2-\mathrm{C}_{2} \mathrm{~B}_{9} \mathrm{H}_{11}\right)_{2}\right], \mathrm{M}=\mathrm{Co},{ }^{9}$ $\mathrm{Cr}^{14}$ (figure 3a); (TMTSF) $\left[3,3^{\prime}-\mathrm{M}\left(1,2-\mathrm{C}_{2} \mathrm{~B}_{9} \mathrm{H}_{11}\right)_{2}\right]$, $\mathrm{M}=\mathrm{Co},{ }^{8} \mathrm{Fe}^{9}$ (figure 4)) are isostructural. A few exceptions (e.g. (TTF) $\left[3,3^{\prime}-\mathrm{Cr}\left(1,2-\mathrm{C}_{2} \mathrm{~B}_{9} \mathrm{H}_{11}\right)_{2}\right]^{13}$ ) are connected with different mutual orientation of the dicarbollide ligands. The asymmetry of charge distribution in the dicarbollide ligand (positive charge on the $\mathrm{CH}$ hydrogen atoms and the most negative charge on the opposite side of the ligand) results in rather high dipole moment of bis(dicarbollide) anion in cisoid conformation and an absence or very low dipole moment in transoid conformation. It could 

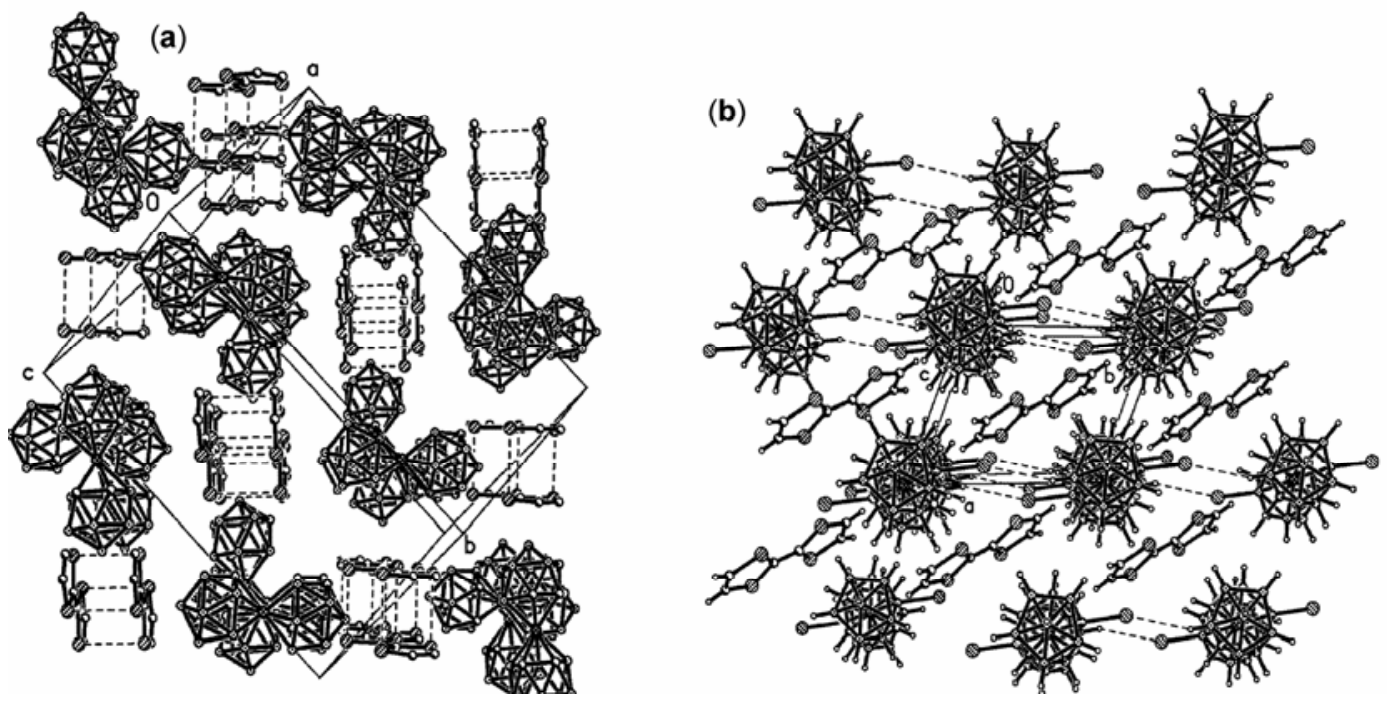

Figure 2. (a) The crystal packing of (TTF) [3, $\left.3^{\prime}-\mathrm{M}\left(1,2-\mathrm{C}_{2} \mathrm{~B}_{9} \mathrm{H}_{11}\right)_{2}\right] \mathrm{M}=\mathrm{Co}$ [8], Fe [13], $\mathrm{Ni}[13]$ and (b) (TTF) $\left[8,8^{\prime}-\mathrm{I}_{2}-3,3^{\prime}-\mathrm{Co}\left(1,2-\mathrm{C}_{2} \mathrm{~B}_{9} \mathrm{H}_{10}\right)_{2}\right][11]$.
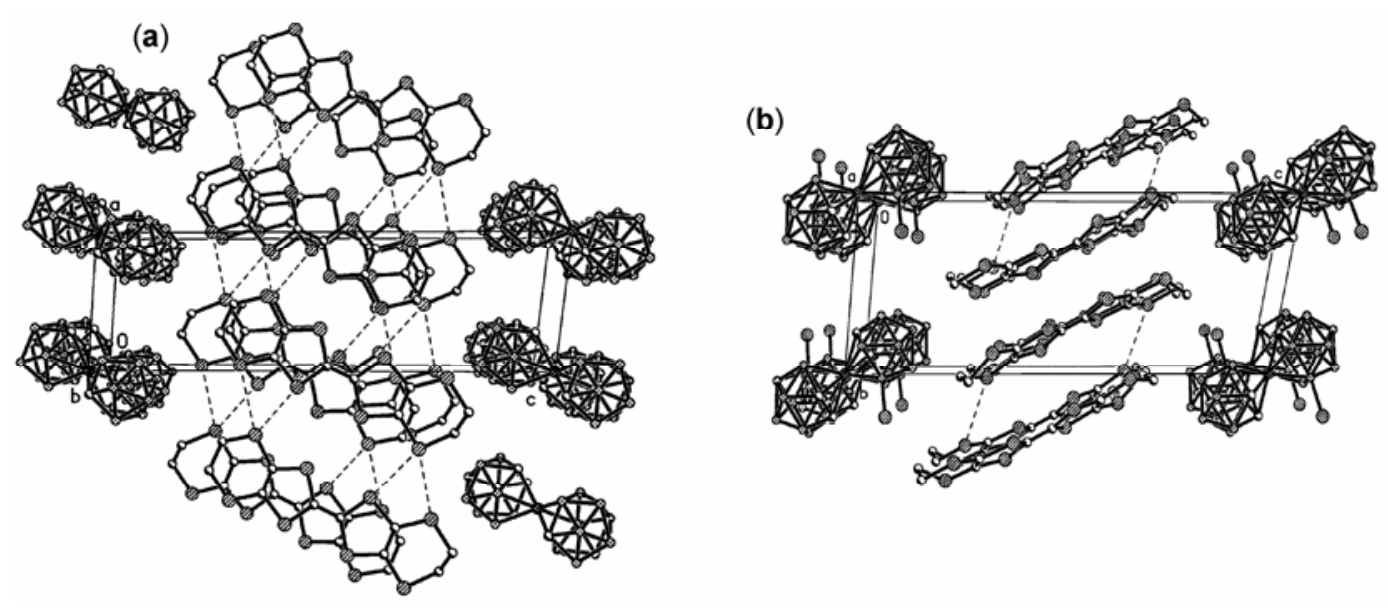

Figure 3. (a) The crystal packing of (BEDT-TTF $)_{2}\left[3,3^{\prime}-\mathrm{M}\left(1,2-\mathrm{C}_{2} \mathrm{~B}_{9} \mathrm{H}_{11}\right)_{2}\right] \mathrm{M}=\mathrm{Co}[9], \mathrm{Cr}$ [14] and (b) $(\mathrm{BEDT}-\mathrm{TTF})_{2}\left[8,8^{\prime}-\mathrm{XY}-3,3^{\prime}-\mathrm{Co}\left(1,2-\mathrm{C}_{2} \mathrm{~B}_{9} \mathrm{H}_{10}\right)_{2}\right] \mathrm{X}=\mathrm{Y}=\mathrm{Br}[10], \mathrm{I}[11] ; \mathrm{X}=\mathrm{I}$, $\mathrm{Y}=\mathrm{H}[9]$.

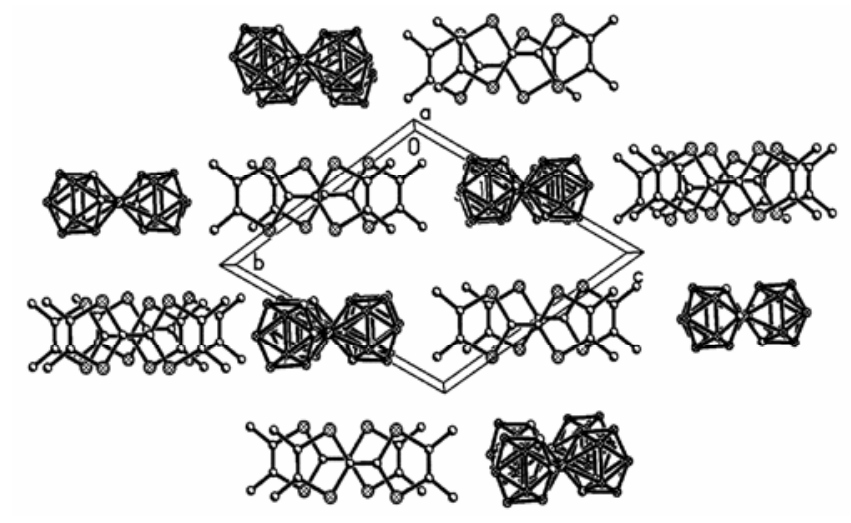

Figure 4. The crystal packing of (TMTSF $)_{2}\left[3,3^{\prime}-\mathrm{M}(1,2-\right.$ $\left.\left.\mathrm{C}_{2} \mathrm{~B}_{9} \mathrm{H}_{11}\right)_{2}\right] \mathrm{M}=\mathrm{Co}$ [8], $\mathrm{Fe}$ [9]. result in different crystal packing bis(dicarbollide) anions in transoid and cisoid conformations.

In general, the difference in energy of rotational conformers and the corresponding rotation barriers in the case of unsubstituted dicarbollide ligands are rather low. ${ }^{15,16}$ As a result, easy rotation of the dicarbollide ligands could produce different conformations under action of small external factors. The difference in the rotational conformer energy could be enlarged by substitution of hydrogen atoms in the dicarbollide ligand for different atoms and groups resulting in stabilization of a single conformer (as a rule transoid one) that promises good reliability of 

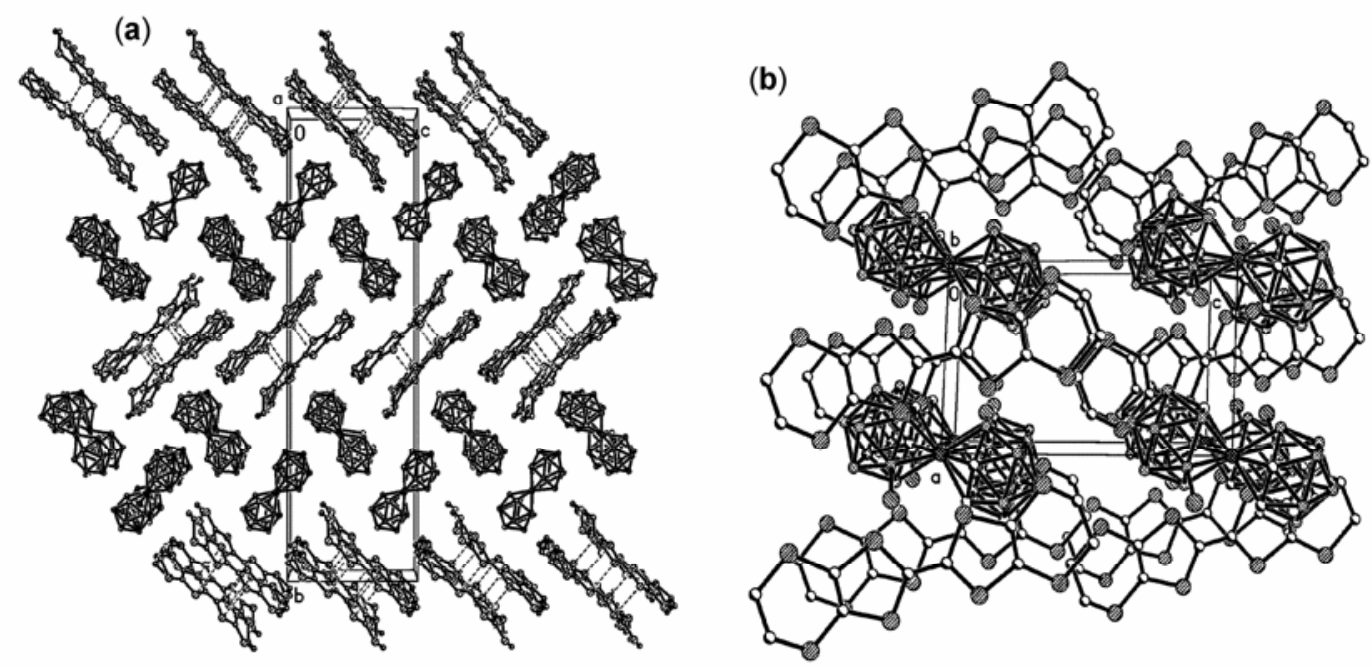

Figure 5. (a) The crystal packing of (BEDT-TTF) $\left[3,3^{\prime}-\mathrm{Co}\left(1,2-\mathrm{C}_{2} \mathrm{~B}_{9} \mathrm{H}_{11}\right)_{2}\right]$ [8] and (b) (BEDT-TTF) [8, $\left.8^{\prime}-\mathrm{Br}_{2}-3,3^{\prime}-\mathrm{Co}\left(1,2-\mathrm{C}_{2} \mathrm{~B}_{9} \mathrm{H}_{10}\right)_{2}\right][10]$.
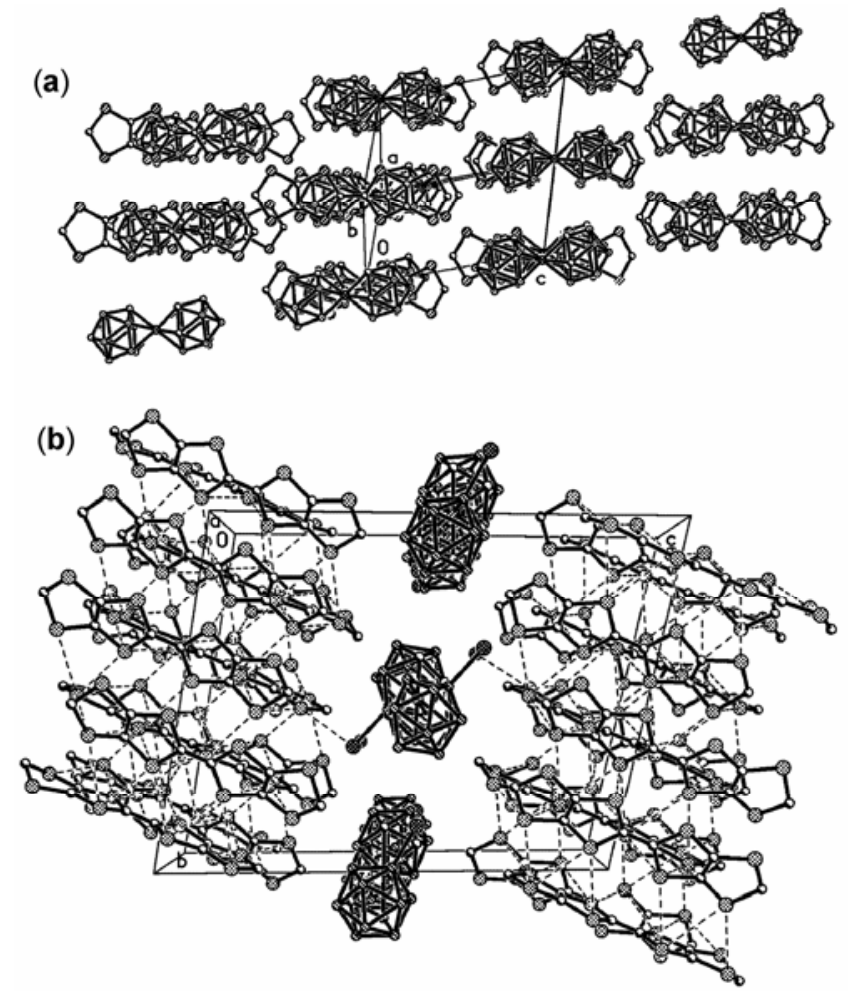

Figure 6. (a) The crystal packing of (BMDT-TTF) [3, $3^{\prime}-$ $\left.\mathrm{Co}\left(1,2-\mathrm{C}_{2} \mathrm{~B}_{9} \mathrm{H}_{11}\right)_{2}\right]$ [9] and (b) (BMDT-TTF) $)_{4}\left[8,8^{\prime}-\mathrm{X}_{2}-\right.$ $\left.3,3^{\prime}-\mathrm{Co}\left(1,2-\mathrm{C}_{2} \mathrm{~B}_{9} \mathrm{H}_{10}\right)_{2}\right] \mathrm{X}=\mathrm{Br}[10], \mathrm{I}[11]$.

the model chosen. On the other hand, an introduction of various substituents in the dicarbollide ligand gives possibility to vary size and shape of the bis(dicarbollide) anions that is an important pre-condition of effective crystal design of molecu- lar materials. As a result, substituted cobalt bis(dicarbollide)s could serve as model compounds for crystal engineering and fine tuning of electric and magnetic properties of molecular materials.

An introduction of halogens at positions 8 and $8^{\prime}$ of cobalt bis(dicarbollide) ${ }^{17}$ was used to fix the transoid conformation. Single crystal X-ray diffraction study demonstrated that substitution of hydrogen atoms for halogens produce different results for radical cation salts of different composition. In the case of the BEDT-TTF - cobalt bis(dicarbollide) salts $2: 1$ an introduction of halogen atoms result in mild transformation of the $\beta^{\prime}$-type layered structure into the $\beta$-type (figure 3 ). In some other cases the substitution of hydrogen atoms for halogens produce radical transformations in crystal packing pattern even in that cases when the overall stoichiometry of the radical cation salt does not change (figures 2 and 5).

In the case of the BMDT-TTF radical cation, an introduction of halogen atoms results in formation of the $4: 1$ complexes with crystal packing of the $\alpha$-type that is unknown for the parent cobalt bis(dicarbollide) (figure 6). The characteristic features of these structures are formation of the $\mathrm{BX}(\mathrm{I}, \mathrm{Br}) \ldots \mathrm{HC}$ hydrogen intermolecular bonds connecting the cobalt bis(dicarbollide) anions into infinite length chains (figure 7) and presence of rather strong BX...S interactions between the cationic and anionic layers.

All the studied tetrafulvalenium salts of the halogen substituted bis(dicarbollide) complexes with the same radical cations and having the same 


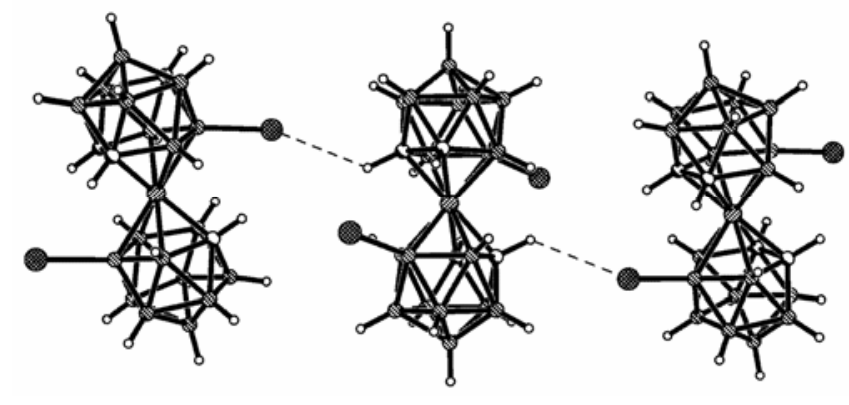

Figure 7. Anion chains in (BMDT-TTF $)_{4}\left[3,3^{\prime}-\mathrm{I}_{2}-3,3^{\prime}-\right.$ $\left.\mathrm{Co}\left(1,2-\mathrm{C}_{2} \mathrm{~B}_{9} \mathrm{H}_{10}\right)_{2}\right][11]$.

stoichiometry ((BMDT-TTF $)_{4}\left[8,8^{\prime}-\mathrm{X}_{2}-3,3^{\prime}-\mathrm{Co}(1,2-\right.$ $\left.\left.\mathrm{C}_{2} \mathrm{~B}_{9} \mathrm{H}_{10}\right)_{2}\right], \quad(\text { BEDT-TTF })_{2} \quad\left[8,8^{\prime}-\mathrm{X}_{2}-3,3^{\prime}-\mathrm{Co}(1,2-\right.$ $\left.\left.\mathrm{C}_{2} \mathrm{~B}_{9} \mathrm{H}_{10}\right)_{2}\right]$ ) were found to be isostructural independently on the halogen atom. The bis (dicarbollide) anions in all these compounds have transoid-conformation.

The study of electrical conductivity of the radical cation salts prepared has demonstrated that all these are semiconductors with the room temperature conductivity is varying from $10^{-4}$ to $15 \mathrm{Ohm}^{-1} \mathrm{~cm}^{-1}$.

\section{Conclusion}

The present available data are not sufficient to cover all field of conventional TTF derivatives and compositions of the radical cation salt, however they are quite enough to predict crystal packing of many radical cation salts and complexes with bis (dicarbollide) anions. The results obtained could be used to design new molecular materials on the basis of the iron group bis(dicarbollide) complexes. Further study is necessary to establish the effect of various transition metals on electric and magnetic transport properties of this type of materials.

\section{Acknowledgements}

This work was supported by the Russian Foundation for Basic Research (Grants 07-03-00712 and 08-0300668 and 08-03-12043), the Russian President Grant (MK-190.2007.3) and the Program of the Presidium of Russian Academy of Sciences 'Development of Methods of Synthesis of Chemical Compounds and Design of New Materials'.

\section{References}

1. Williams J M, Ferraro, J R, Thorn R J, Carlson K D, Geiser U, Wang $\mathrm{H} \mathrm{H}$, Kini A $\mathrm{M}$ and Whangbo $\mathrm{M} \mathrm{H}$ 1992 Organic superconductors (including fullerenes: synthesis, structure, properties and theory) (Englewood Cliffs: Prentice Hall)

2. Ishiguro T, Yamaji K and Saito G 1998 Organic superconductors (Berlin: Springer), 2nd edn

3. Sivaev I B and Bregadze V I 1999 Collect. Czech. Chem. Commun. 64783

4. Sivaev I B and Bregadze V I $2000 \mathrm{~J}$. Organomet. Chem. 614-615 27

5. Yan Y-K and Mingos D M 1995 Chem. Soc. Rev. 203

6. Bregadze V I, Timofeev S V, Sivaev I B and Lobanova I A. 2004 Russ. Chem. Rev. 73470

7. Fourmigue $\mathrm{M}$ and Batail P 2004 Chem. Rev. 104 5379

8. Kazheva O N, Chekhlov A N, Alexandrov G G, Buravov L I, Kravchenko A V, Starodub V A, Sivaev I B, Bregadze V I and Dyachenko O A $2006 \mathrm{~J}$. Organomet. Chem. 6914225

9. Kazheva O N, Alexandrov G G, Kravchenko A V, Starodub V A, Sivaev I B, Lobanova I A, Bregadze V I, Buravov L I and Dyachenko O A 2007 J. Organomet. Chem. 6925033

10. (a) Kazheva O, Alexandrov G, Kravchenko A, Starodub V, Lobanova I, Sivaev I, Bregadze V, Titov L and Dyachenko O 2008 Adv. Sci. Technol. 54 331; (b) Kazheva O, Alexandrov G, Kravchenko A, Starodub V, Lobanova I, Sivaev I, Bregadze V, Buravov L and Dyachenko O 2008 Solid State Sci. 101734

11. Kazheva O N, Alexandrov G G, Kravchenko A V, Starodub V A, Lobanova I A, Sivaev I B, Bregadze V I, Titov L V, Buravov L I. and Dyachenko O A 2009 J. Organomet. Chem. 6942336

12. (a) Coronado E and Day P 2004 Chem. Rev. 104 5419; (b) Ouahab L and Enoki T 2004 Eur. J. Inorg. Chem. 933; (c) Enoki T and Miyazaki A 2004 Chem. Rev. 104 5449; (d) Kobayashi H, Kobayashi A and Cassoux P 2000 Chem. Soc. Rev. 29325

13. Forward J M, Mingos D M P, Muller T E, Williams D J and Yan Y K $1994 J$. Organomet. Chem. 467 207

14. Yan Y K, Mingos D M P, Williams D J and Kurmoo M 1995 J. Chem. Soc., Dalton Trans. 3221

15. (a) Hawthorne M F, Zink J I, Skelton J M, Bayer M J, Liu C, Livshits E, Baer R and Neuhauser D 2004 Science 303 1849; (b) Hawthorne M F, Ramachandran B M, Kennedy R D and Knobler C B 2006 Pure Appl. Chem. 781299

16. (a) Bühl M, Hnyk D and Machaček J 2005 Chem. Eur. J. 11 4109; (b) Bühl M, Holub J, Hnyk D and Machaček J 2006 Organometallics 252173

17. Matel L, Macasek F, Rajec $P$, Heřmanek $S$ and Plešek J 1982 Polyhedron 1511 